\title{
Does long-term fire suppression impact leaf litter breakdown and aquatic invertebrate colonization in pine flatwoods wetlands?
}

\author{
Houston C. Chandler ${ }^{\text {Corresp., 1, }}{ }^{\text {, J. Checo Colón-Gaud }}{ }^{3}$, Thomas A. Gorman ${ }^{1,4}$, Khalil Carson ${ }^{3,5}$, Carola A. Haas ${ }^{1}$ \\ 1 Department of Fish and Wildlife Conservation, Virginia Polytechnic Institute and State University (Virginia Tech), Blacksburg, Virginia, United States \\ 2 The Orianne Society, Tiger, Georgia, United States \\ 3 Department of Biology, Georgia Southern University, Statesboro, Georgia, United States \\ 4 Aquatic Resources Division, Washington State Department of Natural Resources, Olympia, Washington, United States \\ 5 Biological and Environmental Sciences Department, Troy University, Troy, Alabama, United States
}

Corresponding Author: Houston C. Chandler

Email address: houstonc@vt.edu

Ephemeral wetlands are commonly embedded within pine uplands of the southeastern United States. These wetlands support diverse communities but have often been degraded by a lack of growing-season fires that historically maintained the vegetation structure. In the absence of fire, wetlands develop a dense mid-story of woody vegetation that increases canopy cover and decreases the amount of herbaceous vegetation. To understand how reduced fire frequency impacts wetland processes, we measured leaf litter breakdown rates and invertebrate communities using three common plant species (Longleaf Pine [Pinus palustris], Pineland Threeawn Grass [Aristida stricta], and Black Gum [Nyssa sylvatica]) that occur in pine flatwoods wetlands located on Eglin Air Force Base, Florida. We also tested whether or not the overall habitat type within a wetland (fire maintained or fire suppressed) affected these processes. We placed leaf packs containing $15.0 \mathrm{~g}$ of dried leaf litter from each species in both fire-maintained and fire-suppressed sections of three wetlands, removing them after 103-104 days submerged in the wetland. The amount of leaf litter remaining at the end of the study varied across species $(N$. sylvatica $=7.97 \pm 0.17 \mathrm{~g}$, $A$. stricta $=11.84 \pm 0.06 \mathrm{~g}$, and $P$. palustris $=11.37 \pm 0.07 \mathrm{~g}$ [mean $\pm \mathrm{SE}$ ]) and was greater in fire-maintained habitat (leaf type: $F_{2,45}=437.2, P<$ 0.001; habitat type: $F_{1,45}=4.6, P=0.037$ ). We identified an average of $260 \pm 33.5$ (SE) invertebrates per leaf pack (range: 19-1,283), and the most abundant taxonomic groups were Cladocera, Isopoda, Acariformes, and Diptera. Invertebrate relative abundance varied significantly among litter species (approximately $39.9 \pm 9.4$ invertebrates per gram of leaf litter remaining in $N$. sylvatica leaf packs, $27.2 \pm 5.3$ invertebrates per gram of $A$. stricta, and $14.6 \pm 3.1$ invertebrates per gram of $P$. palustris [mean $\pm \mathrm{SE}$ ]) but not habitat type. 
However, both habitat ( $p$ seudo- $F_{1,49}=4.30, P=0.003$ ) and leaf litter type ( $p$ seudo- $F_{2,49}=$ $3.62, P=0.001$ ) had a significant effect on invertebrate community composition. Finally, this work was part of ongoing projects focusing on the conservation of the critically imperiled Reticulated Flatwoods Salamander (Ambystoma bishopi), which breeds exclusively in pine flatwoods wetlands, and we examined the results as they relate to potential prey items for larval flatwoods salamanders. Overall, our results suggest that the vegetation changes associated with a lack of growing-season fires can impact both invertebrate communities and leaf litter breakdown. 
1

2

3

4

5 Houston C. Chandler ${ }^{1,2}$, J. Checo Colón-Gaud ${ }^{3}$, Thomas A. Gorman ${ }^{1,4}$, Khalil Carson ${ }^{3,5}$, and Carola A. Haas ${ }^{1}$

$9{ }^{1}$ Department of Fish and Wildlife Conservation, Virginia Tech, Blacksburg, Virginia, USA

${ }^{2}$ The Orianne Society, Tiger, Georgia, USA

${ }^{3}$ Department of Biology, Georgia Southern University, Statesboro, Georgia, USA

${ }^{4}$ Current address: Aquatic Resources Division, Washington State Department of Natural

Resources, Olympia, Washington, USA

14

Alabama, USA

16

17

Corresponding author:

19

Houston C. Chandler ${ }^{1,2}$

20

Email Address: houstonc@vt.edu 


\section{Abstract}

Ephemeral wetlands are commonly embedded within pine uplands of the southeastern

United States. These wetlands support diverse communities but have often been degraded by a lack of growing-season fires that historically maintained the vegetation structure. In the absence of fire, wetlands develop a dense mid-story of woody vegetation that increases canopy cover and decreases the amount of herbaceous vegetation. To understand how reduced fire frequency impacts wetland processes, we measured leaf litter breakdown rates and invertebrate communities using three common plant species (Longleaf Pine [Pinus palustris], Pineland Threeawn Grass [Aristida stricta], and Black Gum [Nyssa sylvatica]) that occur in pine flatwoods wetlands located on Eglin Air Force Base, Florida. We also tested whether or not the overall habitat type within a wetland (fire maintained or fire suppressed) affected these processes. We placed leaf packs containing $15.0 \mathrm{~g}$ of dried leaf litter from each species in both fire-maintained and fire-suppressed sections of three wetlands, removing them after 103-104 days submerged in the wetland. The amount of leaf litter remaining at the end of the study varied across species $(N$. sylvatica $=7.97 \pm 0.17 \mathrm{~g}$, A. stricta $=11.84 \pm 0.06 \mathrm{~g}$, and P. palustris $=11.37$ $\pm 0.07 \mathrm{~g}[$ mean $\pm \mathrm{SE}]$ ) and was greater in fire-maintained habitat (leaf type: $\mathrm{F}_{2,45}=437.2, P<$ 0.001; habitat type: $\left.\mathrm{F}_{1,45}=4.6, P=0.037\right)$. We identified an average of $260 \pm 33.5$ (SE) invertebrates per leaf pack (range: 19-1,283), and the most abundant taxonomic groups were Cladocera, Isopoda, Acariformes, and Diptera. Invertebrate relative abundance varied significantly among litter species (approximately 39.9 \pm 9.4 invertebrates per gram of leaf litter remaining in $N$. sylvatica leaf packs, $27.2 \pm 5.3$ invertebrates per gram of $A$. stricta, and $14.6 \pm$ 3.1 invertebrates per gram of $P$. palustris $[$ mean $\pm \mathrm{SE}]$ ) but not habitat type. However, both habitat (pseudo- $\left.\mathrm{F}_{1,49}=4.30, P=0.003\right)$ and leaf litter type $\left(\right.$ pseudo- $\left.\mathrm{F}_{2,49}=3.62, P=0.001\right)$ had a 
45 significant effect on invertebrate community composition. Finally, this work was part of ongoing

46 projects focusing on the conservation of the critically imperiled Reticulated Flatwoods

47 Salamander (Ambystoma bishopi), which breeds exclusively in pine flatwoods wetlands, and we

48 examined the results as they relate to potential prey items for larval flatwoods salamanders.

49 Overall, our results suggest that the vegetation changes associated with a lack of growing-season

50 fires can impact both invertebrate communities and leaf litter breakdown. 


\section{Introduction}

53

54

Natural disturbances, events that disrupt an ecosystem or change the physical environment, occur across a variety of both spatial and temporal scales and have historically played a critical role in shaping many ecosystems (White and Pickett 1985; White and Jentsch 2001; Turner 2010). However, anthropogenic activity has caused significant changes to individual disturbance events and to overall disturbance regimes (Johnstone et al. 2016; Newman 2019). These changes are important because disturbances can promote biodiversity and habitat heterogeneity that would otherwise be lost (Carlson et al. 1993; Townsend and Scarsbrook 1997; Conway et al. 2010). Thus, restoring ecologically important disturbances are often the target of active management programs that attempt to emulate natural processes that have been disrupted by anthropogenic activity (Long 2009).

Wildfire is a widespread natural disturbance, impacting a wide variety of terrestrial and aquatic ecosystems (Morgan et al. 2001; Bisson et al. 2003; Mouillot and Field 2005; Butz 2009). In the southeastern United States, the Longleaf Pine (Pinus palustris) ecosystem historically covered an area of approximately 35 million hectares (Frost 1993). Longleaf Pine forests are a classic example of a fire-adapted ecosystem, experiencing frequent low-intensity fires (Henderson 2006; Stambaugh et al. 2011). These regular fires historically maintained vegetation structure (e.g., a pine overstory with thick herbaceous vegetation on the forest floor) and reduced leaf litter and woody debris build up (Brockway and Lewis 1997). In the absence of natural or prescribed fires, Longleaf Pine forests transition to closed-canopy systems with abundant hardwoods in the mid-story and decreased diversity and abundance of herbaceous vegetation on the forest floor (Gilliam and Platt 1999; Glitzenstein et al. 2003). 
Ephemeral wetlands are a common landscape feature in Longleaf Pine forests and are

75

76

77

78

79

80

81

82

83

84

characterized by a regular wetting and drying cycle that is tied to annual variation in

precipitation and evapotranspiration rates. These wetlands are frequently geographically isolated (i.e., lacking a consistent surface water connection to other water bodies; Tiner 2003; Cohen et al. 2016) and commonly support abundant and diverse biotic communities that are dependent on relatively predictable periods of inundation (e.g., Golladay et al. 1997; Kirkman et al. 1999; Erwin et al. 2016). Furthermore, these wetlands are subject to vegetation shifts similar to other Longleaf Pine ecosystems that can occur both from fire suppression and from poorly timed (e.g., during the winter months when wetlands are more likely to have standing water present) prescribed fires (Kirkman 1995; Bishop and Haas 2005). Vegetation shifts change aquatic systems by altering leaf litter inputs, reducing the amount of structure available in the aquatic environment, and impacting other ecosystem processes (Mulhouse et al. 2005; Hinman and Brewer 2007). Ultimately, these types of changes can impact the composition and abundance of aquatic communities (Hornung and Foote 2006; Chandler et al. 2015).

Aquatic invertebrate communities are a critical component of ephemeral wetlands (Batzer and Wissinger 1996; McInerney et al. 2017), functioning across multiple trophic levels by acting as both a prey base for other species and as predators in generally fishless environments (Murkin and Wrubleski 1988; Batzer and Wissinger 1996). Ephemeral wetlands can also support higher aquatic invertebrate biomass and differing community composition when compared to permanent wetlands with fish populations (Zimmer et al. 2001; McInerney et al. 2017). One of the important roles that invertebrates play in wetland ecosystems is contributing to leaf litter breakdown by consuming and physically breaking down leaf litter that falls into the wetland basin (Fazi and Rossi 2000; Gingerich et al. 2015). Breakdown rates can vary widely across 
97 different leaf litter species (Leroy and Marks 2006), and litter inputs into the wetland can broadly

98 impact both biotic and abiotic processes (Stoler and Relyea 2016). The structure, nutrient content, and availability of individual leaf litter species can all impact the invertebrate community, with effects potentially transitioning to higher trophic levels (Batzer and Palik 2007; Stoler and Relyea 2016).

Here, we describe the results of a field experiment testing the effects of habitat type (i.e., fire maintained vs. fire suppressed) on leaf litter breakdown and invertebrate communities in pine flatwoods wetlands. We assessed these environmental processes for three species of leaf litter: Longleaf Pine (P. palustris), Pineland Threeawn Grass, commonly referred to as wiregrass, (Aristida stricta), and Black Gum (Nyssa sylvatica). Pinus palustris and A. stricta are commonly found in fire-maintained wetlands, while $N$. sylvatica is mostly restricted to wetlands with reduced fire frequency or deeper portions of wetlands that are less likely to experience regular fires (Chandler 2015). We predicted that fire-maintained sections of wetlands would support more abundant invertebrate communities, leading to higher breakdown rates. Furthermore, we predicted that $P$. palustris and $A$. stricta would breakdown more slowly than $N$. sylvatica because

112 of lower surface area for invertebrate colonization. Finally, we assessed invertebrate communities overall and specifically focused on taxa that are important food sources for larval (USFWS 2009). Larval flatwoods salamanders feed primarily on aquatic invertebrates (e.g., Isopoda, Amphipoda, and Copepoda) and, while little is known about foraging behavior, opportunistic observations suggest that larvae forage in and around herbaceous vegetation as well as along benthic substrates (Palis 1996; Sekerak et al. 1996; Whiles et al. 2004). 
120 Materials \& Methods

121 Study Sites

122 All field work was conducted on Eglin Air Force Base (Eglin) and access to field sites 123 was approved by the U.S. Fish and Wildlife Service and Jackson Guard (Eglin's Natural Resources 124 Division; Cooperative Agreement Number F14AC00068). Eglin is a large military installation covering over 188,459 ha of the Florida panhandle's Gulf Coastal Plain. Consisting largely of

126 sandhills and other upland habitat, Eglin also contains some of the best remaining examples of

127 mesic pine flatwoods. These forests have sandy, poorly drained soils and ephemeral,

128 geographically isolated wetlands embedded within the surrounding pine forest. Eglin has an 129 extensive active habitat management program that routinely applies prescribed fire to pine 130 forests across the installation. However, there have been persistent challenges associated with 131 burning inside of wetland basins, and most pine flatwoods wetlands on the installation were 132 either partially or completely degraded by long-term fire suppression and exclusion. Pine 133 flatwoods wetlands on Eglin support diverse amphibian communities, including breeding 134 populations of Reticulated Flatwoods Salamanders (USFWS 2009). During their aquatic larval 135 phase, flatwoods salamanders depredate a variety of freshwater invertebrate groups (Whiles et al. 136 2004), serving as important predators in the wetlands that they inhabit.

Study Design

We collected leaf litter from the three species of interest (P.palustris, A. stricta, and N. 140 sylvatica) in areas surrounding pine flatwoods wetlands on Eglin. We raked $P$. palustris needles 141 from underneath large trees, collected $N$. sylvatica leaves from plants that had been manually 142 removed from wetlands, and collected A. stricta material from standing dead stems at the end of 
143 the reproductive period. We dried all leaf litter at room temperature for approximately one week.

144 We then filled coarse mesh bags (8-mm openings), allowing for invertebrate colonization, with

$14515.0 \mathrm{~g}$ of dried leaf litter from a single species.

146 We placed a total of 72 leaf packs across three pine flatwoods wetlands on Eglin that

147 were part of long-term monitoring projects focused on wetland communities and management

148 (e.g., Gorman et al. 2013). We selected wetlands that had areas of both high (fire maintained)

149 and low (fire suppressed) herbaceous vegetation cover. We note here that we chose wetlands

150 based on their vegetation characteristics and not on a specific fire history. All wetlands are

151 located in actively managed pine flatwoods on Eglin with similar overall management histories.

152 Based on limited data, wetland basins included in this study experienced 2-3 prescribed fires

153 from 2012-2015, and we documented fire effects $86 \%$ of the time in fire-maintained sections

154 and $29 \%$ of the time in fire-suppressed sections (based leaf pack locations). Furthermore, current

155 conditions are the result of multiple management activities, including both prescribed fire and

156 mechanical removal of woody vegetation (Gorman et al. 2013).

157 In each wetland, we deployed leaf packs along 10-m transects in both habitat types,

158 placing one leaf pack of each plant species at both ends and in the middle of the transect (9 per

159 transect and 18 per wetland). We separated individual leaf packs by approximately $30 \mathrm{~cm}$

160 perpendicular to the transect. We added leaf packs to wetlands on 10 and 11 November 2015 and

161 secured them to the bottom of the wetland using metal gardening stakes. Finally, in one wetland,

162 we doubled the number of leaf packs to examine the effects of time submerged on breakdown

163 and invertebrate communities (logistical constraints prevented this effort in all wetlands). We

164 positioned these leaf packs adjacent to the same transect, placing leaf packs containing the same

165 plant species next to one another. 
167 packs at two time periods. First, we collected the leaf packs from the additional replicate in the

168 single wetland on 5 December 2015 (25 days submerged). All other leaf packs were removed

169 from wetlands on 22 February 2016 (103-104 days submerged). Upon removal from the

170 wetland, we immediately placed all leaf packs in $95 \%$ ethanol to stop further decomposition of

171 leaf material and to preserve invertebrates until samples could be processed.

172 We washed all of the remaining leaf litter to separate out invertebrates using a $125 \mu \mathrm{m}$

173 sieve. All remaining material from the leaf packs was then dried at $55^{\circ} \mathrm{C}$ for at least 48 hours.

174 We then weighed this material to obtain dry mass (DM). Next, we ground samples into a fine

175 powder by milling at 25,000 rpm for either 90 seconds (N. sylvatica) or 180 seconds (P. palustris

176 and A. stricta) (IKA® Tube Mill 100 control). We burned ground samples in a muffle furnace at

$177500^{\circ} \mathrm{C}$ for 1 hour to obtain ash-free dry mass (AFDM). For the 25-day replicate, we burned the

178 entire sample, while we burned approximately $1 \mathrm{~g}$ of the 103-104-day samples and calculated

179 the AFDM from this subsample. We used the AFDM of each sample to calculate the processing

180 coefficient (k) using the exponential decay model (Petersen and Cummins 1974; Maloney and

181 Lamberti 1995; Benfield et al. 2017). We used the estimated processing coefficients to calculate

182 number of days it would take for $99 \%$ of the sample to breakdown. Finally, we identified all

183 invertebrates to broad taxonomic groups that were easily identifiable (order in most cases).

In addition to leaf packs, we also quantified herbaceous vegetation cover and canopy

cover as part of other ongoing projects. Herbaceous vegetation and canopy cover were measured at points along each wetland's longest axis, partially overlapping the locations with litter bags

(Gorman et al. 2013). We estimated the percent herbaceous vegetation cover using a $0.5 \mathrm{~m} \mathrm{X} 0.2$ 
189

190

191

192

193

194

195

196

197

198

199

200

201

202

203

204

205

206

207

208

209

210

211

canopy cover by averaging the canopy cover recorded in each of the four cardinal directions with a convex spherical densiometer. All vegetation data were collected during the fall of 2014, and for this assessment, we included the two sampling locations that were closest to the leaf litter bags.

Statistical Analyses

Prior to all analyses, we excluded all results from one 104-day leaf pack (A. stricta, firesuppressed habitat) and the invertebrate results from a one 25-day leaf pack (P. palustris, firemaintained habitat) because these data were not consistent with the other results. Furthermore, we only included data from leaf packs submerged for 103-104 days in the following analyses. We tested for an effect of leaf litter species and habitat type (fire suppressed or maintained) on leaf litter breakdown and invertebrate abundance using a series of linear mixed effects models (LMM). First, we fit a mixed effects model to test for the effects of litter species and habitat type on the amount of leaf litter remaining at the end of the experiment. We treated the wetland as a random effect to account for non-independence in the leaf packs collected from the same wetland. Leaf litter species, habitat type, and their interaction were included in the model as fixed effects. Second, we fit two similar models using the total invertebrate abundance and the abundance of groups that make up the primary components of the larval flatwoods salamander diet. We defined these groups as Isopoda, Amphipoda, and Copepoda, which make up approximately $65 \%$ of prey items found in larval flatwoods salamander stomachs (Whiles et al. 2004). Both measures of invertebrate abundance were standardized by the mass remaining in their respective leaf pack prior to analyses. Invertebrate models also contained leaf species, habitat type, and their interaction as fixed effects and wetland as a random effect. We verified 
212 that the assumptions of linearity, normality, and homogeneity of the residuals were met in all

213 three models using diagnostic plots. Finally, we performed pairwise comparisons using Tukey's

214 HSD when tests on main effects indicated a significant difference among leaf litter species.

215 To further examine the composition of invertebrate communities, we visualized the

216 community data using a non-metric multidimensional scaling (NMDS) plot. We graphed

217 community data using Bray-Curtis dissimilarities and verified that the Stress tatistic for the

218 NMDS was less than 0.2 (Clarke 1993). We tested for differences in community composition

219 among leaf litter species and habitat type using a distance-based permutational multi-variate

220 analysis of variance (PERMANOVA; Anderson and Walsh 2013). We conducted the

221 PERMANOVA using Bray-Curtis dissimilarity indices and 999 permutations. The individual

222 wetland was treated as a block in this analysis, and we tested for significance using the marginal

223 effects. We also tested for differences in group dispersions (variance) following Anderson

224 (2006). All statistical analyses were performed in R (R Core Team 2020), and NMDS,

225 PERMANOVA, and tests for dispersion were available in the vegan package (Oksanen et al.

226 2015). Mixed models were fit using the lme4 package (Bates et al. 2015), and pairwise

227 comparisons were performed using the emmeans package (Lenth 2021).

228

229 Results

230 Across all three leaf species and both habitat types, the rate of mass loss was highest

231 during the first 25 days after being submerged (Fig. 1). After 103-104 days submerged, $N$.

232 sylvatica had the fastest mean k rate $(-0.0062 \pm 0.0002$ [SE] followed by P. palustris $(-0.0027$

$233 \pm 0.00006[\mathrm{SE}])$ and $A$. stricta $(-0.0023 \pm 0.00005[\mathrm{SE}])$. There was no interaction effect

234 between habitat and leaf type on the amount of leaf litter remaining after 103-104 days in the 
235 wetland (LMM: $\left.\mathrm{F}_{2,45}=2.0, P=0.15\right)$. However, both habitat $\left(\mathrm{LMM}: \mathrm{F}_{1,45}=4.6, P=0.037\right)$ and

236 leaf type $\left(\mathrm{LMM}: \mathrm{F}_{2,45}=437.2, P<0.001\right)$ significantly impacted leaf litter breakdown after 104

237 days (Fig. 1; Tables 1 and 2). Nyssa sylvatica (weight remaining $=7.97 \pm 0.17 \mathrm{~g}[\mathrm{mean} \pm \mathrm{SE}]$ )

238 leaves broke down faster than both $P$. palustris (weight remaining $=11.37 \pm 0.07 \mathrm{~g}[\mathrm{mean} \pm \mathrm{SE}]$ )

$239(P<0.0001)$ and $A$. stricta (weight remaining: $=11.84 \pm 0.06 \mathrm{~g}[\mathrm{mean} \pm \mathrm{SE}])$. Breakdown was

240 slower, on average, in fire-suppressed sections of wetlands. However, the effect was small

241 compared to the differences between leaf types and was not consistent across wetlands (Table 1).

242 We identified a total of 2,677 invertebrates in leaf packs (mean: 158 per pack, range: 14-

243 379, SE: 32.2) collected after 25 days submerged and 14,062 invertebrates in leaf packs (mean:

244260 per pack, range: 19-1,283, SE: 33.5) collected after 103-104 days submerged. The most

245 abundant invertebrate groups were Cladocera, Isopoda, Acariformes, and Diptera, accounting for

246 approximately $93 \%$ of all invertebrates identified across all samples (Table 3). For leaf packs

247 submerged 103-104 days, there was no interaction effect between litter species and habitat type

248 on the total invertebrate relative abundance $\left(\mathrm{LMM}: \mathrm{F}_{2,45}=0.52, P=0.60\right)$ or on the relative

249 abundance of preferred flatwoods salamander prey items (LMM: $\left.\mathrm{F}_{2,45}=0.12, P=0.88\right)$. Leaf

250 type but not habitat type affected both overall invertebrate relative abundance (LMM: Leaf: $F_{2,45}$

$251=3.98, P=0.03$; Habitat: $\left.\mathrm{F}_{1,45}=0.70, P=0.41\right)$ and the relative abundance of flatwoods

252 salamander prey items (LMM: Leaf: $\mathrm{F}_{2,45}=13.4, P=0.00003$; Habitat: $\mathrm{F}_{1,45}=0.40, P=0.53$;

253 Table 2). Nyssa sylvatica leaf packs $(39.9 \pm 9.4[$ mean \pm SE] invertebrates per gram of leaf litter

254 remaining) had higher total invertebrate relative abundance than P.palustris (14.6 \pm 3.1 [mean \pm

$255 \mathrm{SE}]$ invertebrates per gram of leaf litter remaining; Tukey's HSD: $\left.\mathrm{t}_{45}=2.8, P=0.007\right)$ but $\operatorname{not} A$.

256 stricta $\left(27.2 \pm 5.3\right.$ [mean $\pm \mathrm{SE}$ ] invertebrates per gram of leaf litter remaining; Tukey’s HSD: $\mathrm{t}_{45}$

$257=1.4, P=0.17)$. Similarly, $N$. sylvatica leaf packs $(17.4 \pm 2.8[$ mean $\pm \mathrm{SE}]$ invertebrates per 
258 gram of leaf litter remaining) had higher flatwoods salamander prey relative abundance than $P$.

259 palustris $(4.3 \pm 0.9$ [mean $\pm \mathrm{SE}]$ invertebrates per gram of leaf litter remaining) and $A$. stricta

$260\left(8.8 \pm 1.3[\right.$ mean $\pm \mathrm{SE}]$ invertebrates per gram of leaf litter remaining) (Tukey’s HSD: $\mathrm{t}_{45}=5.1$

$261 P<0.0001$ and $\mathrm{t}_{45}=3.3, P=0.002$, respectively) (Fig. 2).

262

The NMDS ordination showed only marginal separation among habitat types and larger

263 separation among leaf types (Stress =0.13; Fig. 3). The PERMANOVA indicated that both

264 habitat (PERMANOVA: pseudo- $\mathrm{F}_{1,49}=4.30, P=0.003$ ) and leaf litter type (PERMANOVA:

265 pseudo- $\left.\mathrm{F}_{2,49}=3.62, P=0.001\right)$ were significantly affecting invertebrate community

266 composition. Similar to the above results, invertebrate communities observed on N. sylvatica had

267 larger differences from those observed on P. palustris and A. stricta leaf litter, while the

268 community observed on $P$. palustris almost completely overlapped the community observed on

269 A. stricta (Fig. 3). The distance-based tests for homogeneity of community dispersions indicated

270 that variation was similar across groups (Leaf: $p s e d o-\mathrm{F}_{2,50}=0.1 .6, P=0.23$; Habitat: $p s e d o-\mathrm{F}_{1,51}$

$271=0.98, P=0.34)$.

272

Environmental characteristics varied across the fire-maintained and fire-suppressed

273

274

275

276

277

278

279

280 sections of wetlands. Herbaceous vegetation cover was nearly absent from fire-suppressed sections of the three wetlands $(2.5 \pm 0.0 \%$ in each wetland [mean $\pm \mathrm{SE}])$, while canopy cover showed more variation across the three wetlands (33-92\%). In the fire-maintained habitat, herbaceous vegetation cover ranged from $63-85 \%$, and canopy cover ranged from $8-16 \%$.

\section{Discussion}

The ecology of pine flatwoods wetlands is primarily regulated by wetland hydrology and fire regime. Both of these factors directly impact floral and faunal communities within wetlands 
281 along with a variety of biotic and abiotic processes that shape wetland ecosystems (Brockway 282 and Lewis 1997; Powell et al. 2005; Gorman et al. 2009; Watts 2013). Our results indicate that

283 vegetation community composition within pine flatwoods wetlands impacts both leaf litter

284 breakdown and aquatic invertebrate communities. Overall, leaf species had a larger effect on

285 these processes than the broad vegetation characteristics within a wetland. However, in natural

286 wetlands, leaf species and vegetation characteristics are fundamentally linked because certain

287 tree and shrub species (i.e., ones that increase canopy cover) are generally limited to either fire-

288 suppressed sections of wetlands or the deepest areas in fire-maintained wetlands (Kirkman

289 1995). Our results, along with other work, strongly indicate that altered fire regimes (particularly

290 a loss of growing-season fire) fundamentally alter wetland ecosystems that are embedded within

291 fire dependent landscapes (de Szalay and Resh 1997; Bixby et al. 2015; Chandler et al. 2015).

Over the course of our study, a majority of the observed mass loss in all three leaf species

293

294

295

296

297

298

299

300

301

302

303

occurred within 25 days of leaf packs being submerged. This rapid initial breakdown is generally

driven by a combination of microbial activity and leaching of secondary compounds into the aquatic environment (Tietema and Wessel 1993). After this initial period, N. sylvatica leaves continued to break down, while both $P$. palustris and $A$. stricta leaf packs lost little mass after the initial period. Over the entire study period, N. sylvatica leaf packs lost approximately 15-28\% more mass than either $P$. palustris or $A$. stricta. The decay rates that we observed for $N$. sylvatica are similar to those previously reported (Battle and Golladay 2001; Battle and Golladay 2007). Interspecific differences in leaf litter breakdown can be attributed to the chemical make-up of the leaves (Battle and Golladay 2007) and the abundance of invertebrates, particularly shredders, present (Tiegs et al. 2008), although the effects of invertebrates on leaf breakdown are variable across studies (Battle and Golladay 2001; Fuell et al. 2013). Our results showed that N. sylvatica 
304 leaf packs contained more invertebrates relative to the amount of material remaining, possibly

305 contributing to their continued breakdown across the entire 104-day period.

We also observed differences in breakdown rates between habitat types, although these

307 effects were smaller overall and appeared to vary among the three wetlands. Leaf litter

308 breakdown in ephemeral wetlands is driven by multiple processes that span both aquatic and

309 terrestrial environments, such as water temperature, water chemistry, flooding regime (both

310 depth and hydroperiod), and the above-mentioned biotic factors (Álvarez and Bécares 2006;

311 Battle and Golladay. 2007; Gingrich et al. 2015). Canopy cover was variable across the three

312 wetlands included in this study, potentially influencing the breakdown rate between habitat types

313 in individual wetlands by impacting water temperatures (Werner and Glennemeir 1999; Becker

314 et al. 2012). This interpretation is supported by our observation that the largest within-wetland

315 difference in breakdown rates occurred in the wetland with the highest canopy cover in the fire-

316 suppressed section (i.e., 92\% in Pond 53 compared to just $62 \%$ and $33 \%$ in Ponds 12 and 16 ,

317 respectively; Table 1). All fire suppressed sections of wetlands had almost no herbaceous

318 vegetation but the variability in canopy cover may reflect differences in the severity of fire

319 suppression or in the species composition of the mid-story vegetation (Peterson and Reich 2008).

320 While none of the wetlands experienced fire during our study, fires can impact water quality

321 within wetlands, potentially altering breakdown rates (Battle and Golladay 2003). Overall, it

322 appears that differences between fire-suppressed and fire-maintained habitats may alter leaf

323 breakdown rates in some cases, but that these effects are inconsistent and small compared to

324 differences between leaf litter types.

Observed differences in invertebrate relative abundance were attributed to the different

326 leaf litter species but not to the overall habitat type. Across both habitat types, N. sylvatica leaf 
327 packs tended to support more abundant invertebrate communities relative to the amount of leaf

328 litter remaining at the end of the study. Higher invertebrate abundance may be related to

329 differences in leaf structure for invertebrate colonization (e.g., complex N. sylvatica leaves vs.

330 cylindrical $P$. palustris needles and $A$. stricta stalks). Greater complexity and surface area can

331 increase the abundance and diversity of invertebrate colonizers (Beckett et al. 1992; Jeffries

332 1993). Furthermore, leaf litter quality is often hypothesized to account for differences in

333 invertebrate abundance across leaf species, and coniferous leaf litter has lower nutrient quality

334 when compared to deciduous leaf litter (Polyakova and Billor 2007; Hisabae et al. 2010).

335 However, coniferous leaf litter can be an important food resource for invertebrate communities

336 when other litter types are scare (Sakai et al. 2016), which may be the case in fire-maintained

337 pine flatwoods wetlands where deciduous leaf litter is generally absent.

338 Our results indicated that there was little effect of overall habitat type on invertebrate

339 relative abundance when sampling using leaf packs. These results starkly contract some of our

340 previous survey work in these wetlands that used dip net surveys to quantify invertebrate

341 communities and showed a large difference across fire-maintained and fire-suppressed habitats

342 (Chandler et al. 2015). These observed differences between studies are likely driven by the

343 different sampling methodologies employed (i.e., sampling in the water column vs. colonization

344 in leaf packs). Ultimately, both leaf packs and dip net surveys over relatively small temporal and

345 spatial scales are only targeting a subset of the aquatic invertebrate communities in these

346 wetlands. In tandem, the results reported here and from Chandler et al. (2015) indicate that

347 invertebrate abundance is likely similar throughout wetland habitat types but that both the

348 composition and spatial arrangement (i.e., in leaf litter vs. in standing herbaceous vegetation) of

349 invertebrate communities varies across habitats. 

implications for flatwoods salamanders because larvae are primarily found in areas with thick

352

353

herbaceous vegetation (Sekerak et al. 1996; Gorman et al. 2009), and wetlands lacking sufficient area with dense herbaceous vegetation support few or no flatwoods salamanders (Brooks et al. 2019, Wendt et al. 2021). This association may be linked to egg deposition sites (Gorman et al. 2014) but could also reduce predation pressure, increase foraging opportunities for larvae, or both. Limited observations suggest that larval flatwoods salamanders forage in and around herbaceous vegetation and along wetland basins (Palis 1996; Sekerak et al. 1996; Whiles et al. 2004), but larvae can be forced into deeper areas with high canopy cover and little herbaceous vegetation when wetland drying occurs (Chandler et al. 2017). Of the three most common invertebrate groups found in larval flatwoods salamander stomachs, Isopoda was by far the most abundant in leaf packs, regardless of litter species or habitat type, suggesting that isopods are a plentiful food source in most wetlands. Even though there were no differences in the overall abundance of the three most abundant invertebrate groups predated by flatwoods salamander larvae across habitat types, Cladocera abundance was higher in fire-maintained sections of wetlands, and these small crustaceans are an important part of the diets of small salamander larvae (Whiles et al. 2004). Overall, during a typical cycle of wetland flooding, invertebrate abundance appears unlikely to be a limiting factor for flatwoods salamander larvae but both hydroperiod and the timing of flooding could significantly impact invertebrate community composition and abundance (Gleason and Rooney 2017).

Compared to many lotic systems, the available information on nutrient cycling, leaf breakdown, and invertebrate communities in ephemeral wetlands embedded within Longleaf Pine forests is minimal. Our study was limited in scope, and future studies could expand on this 
373 work in several ways. First, to acquire a more comprehensive understanding of this ecosystem, a

374 complete inventory of aquatic invertebrate species could be conducted in these wetlands,

375 focusing on identifying invertebrates to lower taxonomic levels. Higher taxonomic resolution

376 would allow for a better assessment of the role that specific invertebrates fill in wetland food

377 webs (e.g., Golladay et al. 1997). Second, the shrub layers that develop in fire-suppressed

378 wetlands are diverse, both in terms of species composition and leaf characteristics. Other

379 common shrub species (e.g., members of the genus Ilex) may have different effects on

380 invertebrate communities than those observed in this study. Furthermore, examining the

381 chemical composition of common litter types would shed light on the causal relationships

382 between litter quality and invertebrate abundance. Third, there is a paucity of data on water

383 quality and broader nutrient cycling in pine flatwoods wetlands (but see Sun et al. 2006). Finally,

384 our study only examined leaf breakdown and invertebrate communities across a continuously

385 flooded time period. However, hydrology, especially wetland drying, can have significant effects

386 on these processes (Battle and Golladay 2007; Gleason and Rooney 2017), and vegetation

387 community composition can in turn impact wetland hydrology (McLaughlin et al. 2013;

388 Golladay et al. 2021).

389

390 Conclusions

391 Our study adds to the large body of literature demonstrating the effects of historic and

392 contemporary fire suppression and exclusion on pine ecosystems in the southeastern United

393 States. Our results indicated that vegetation changes associated with a lack of growing-season

394 fires can alter both breakdown and invertebrate communities in wetland systems. Leaf litter

395 inputs into wetlands form the foundation of aquatic food webs and contribute to the overall 
396 cycling of nutrients within the wetland. These processes are also linked to the surrounding

397 uplands through annual movements of animals into and out of wetlands in response to flooding 398 events (Smith et al. 2019). Ultimately, management of pine flatwoods wetlands should prioritize

399 maintaining or restoring vegetation structure characteristic of a fire-dependent ecosystem 400 through a combination of mechanical treatments and prescribed fire applied during the growing 401 season or most importantly when wetlands are dry, allowing fire to carry through wetland basins 402 (Gorman et al. 2013).

403

404

\section{Acknowledgements}

405

We thank the many people who assisted with study design, fieldwork, and sample

406

processing, especially B. Chandler, R. Chandler, K. Jones, M. Cawthorn, B. Collins, M.

407

McKeon, B. Rincon, and T. Williams. The manuscript was improved by comments from two

408

anonymous reviewers. Logistical support was provided by Jackson Guard (Eglin Air Force

409

Base's Natural Resources Division), the Virginia Tech Department of Fish and Wildlife

410

Conservation, and the Georgia Southern University Department of Biology.

\section{References}

Álvarez, J. A., and E. Bécares. 2006. Seasonal decomposition of Typha latifolia in a free-water surface constructed wetland. Ecological Engineering 28:99-105.

Anderson, M. J. 2006. Distance-based tests for homogeneity of multivariate dispersions. Biometrics 62:245-253. 
417 Anderson, M. J., and D. C. Walsh. 2013. PERMANOVA, ANOSIM, and the Mantel test in the

420

421

422

423

424

425

426

427

428

429

430

431

432

433

434

435

436

437

438
418 face of heterogeneous dispersions: What null hypothesis are you testing? Ecological Monographs 83:557-574.

Bates, D., M. Maechler, B. Bolker, and S. Walker. 2015. Fitting linear mixed-effects models using lme4. Journal of Statistical Software 67:1-48.

Battle, J. M., and S. W. Golladay. 2001. Hydroperiod influence on breakdown of leaf litter in cypress-gum wetlands. The American Midland Naturalist 146:128-145.

Battle, J., and S. W. Golladay. 2003. Prescribed fire's impact on water quality of depressional wetlands in southwestern Georgia. American Midland Naturalist 150:15-25.

Battle, J. M., and S. W. Golladay. 2007. How hydrology, habitat type, and litter quality affect leaf breakdown in wetlands on the Gulf Coastal Plain of Georgia. Wetlands 27:251-260.

Batzer, D. P., and B. J. Palik. 2007. Variable response by aquatic invertebrates to experimental manipulations of leaf litter input into seasonal woodland ponds. Fundamental and Applied Limnology 168:155-162.

Batzer, D. P., and S. A. Wissinger. 1996. Ecology of insect communities in nontidal wetlands. Annual Review of Entomology 41:75-100.

Becker, C. G., D. Rodriguez, A. V. Longo, A. L. Talaba, and K. R. Zamudio. 2012. Disease risk in temperate amphibian populations is higher at closed-canopy sites. PloS ONE 7:e48205.

Beckett, D.C., T. P. Aartila, and A. C. Miller. 1992. Invertebrate abundance on Potamogeton nodosus: Effects of plant surface area and condition. Canadian Journal of Zoology 70:300-306. 
439 Benfield, E. F., K. M. Fritz, and S. D. Tiegs. 2017. Leaf litter breakdown. Pp. 71-82 in F. R.

440 Hauer and G. A. Lamberti GA, eds. Methods in Stream Ecology. Volume 2: Ecosystem $441 \quad$ Function. Elsevier, London, England.

442 Bishop, D. C., and C. A. Haas. 2005. Burning trends and potential negative impacts on flatwoods salamanders. Natural Areas Journal 25:290-294.

Bisson, P. A., B. E. Rieman, C. Luce, P. F. Hessburrg, D. C. Lee, J. L. Kershner, G. H. Reeves, and R. E. Gresswell. 2003. Fire and aquatic ecosystems of the western USA: Current knowledge and key questions. Forest Ecology and Management 178:213-229.

447

448

449

450

451

452

453

454

455

456

457

458

459

460

461

Bixby, R. J., S. D. Cooper, R. E. Gresswell, L. E. Brown, C. N. Dahm, and K. A. Dwire. 2015. Fire effects on aquatic ecosystems: An assessment of the current state of the science. Freshwater Science 34:1340-1350.

Brockway, D. G., and C. E. Lewis. 1997. Long-term effects of dormant-season prescribed fire on plant community diversity, structure and productivity in a longleaf pine wiregrass ecosystem. Forest Ecology and Management 96:167-183.

Brooks, G. C., J. A. Smith, E. A. Frimpong, T. A. Gorman, H. C. Chandler, and C. A. Haas. 2019. Indirect connectivity estimates of amphibian breeding wetlands from spatially explicit occupancy models. Aquatic Conservation: Marine and Freshwater Ecosystems 29:1815-1825.

Butz, R. J. 2009. Traditional fire management: Historical fire regimes and land use change in pastoral East Africa. International Journal of Wildland Fire 18:442-450.

Carlson, P. C., G. W. Tanner, J. M. Wood, and S. R. Humphrey. 1993. Fire in key deer habitat improves browse, prevents succession, and preserves endemic herbs. The Journal of Wildlife Management 57:914-928. 
462 Chandler, H. C. 2015. The effects of climate change and long-term fire suppression on

463

464

465

466

467

468

469

470

471

472

473

474

475

476

477

478

479

480

481

482

483

484

ephemeral pond communities in the southeastern United States. Thesis, Virginia Tech. Blacksburg, Virginia, USA.

Chandler, H. C., C. A. Haas, and T. A. Gorman. 2015. The effects of habitat structure on winter aquatic invertebrate and amphibian communities in pine flatwoods wetlands. Wetlands $35: 1201-1211$.

Chandler, H. C., D. L. McLaughlin, T. A. Gorman, K. J. McGuire, J. B. Feaga, and C. A. Haas. 2017. Drying rates of ephemeral wetlands: Implications for breeding amphibians. Wetlands 37:545-557.

Clarke, K. R., 1993. Non-parametric multivariate analysis of changes in community structure. Australian Journal of Ecology 18:117-143.

Cohen, M. J., I. F. Creed, L. Alexander, N. B. Basu, A. J. K. Calhoun, C. Craft, E. D’Amico, E. DeKeyser, L. Fowler, H. E. Golden, J. W. Jawitz, P. Kalla, L. K. Kirkman, C. R. Lane, M. Lang, S. G. Leibowitz, D. B. Lewis, J. Marton, D. L. McLaughlin, D. M. Mushet, H. Raanan-Kiperwas, M. C. Rains, L. Smith, and S. C. Walls. 2016. Do geographically isolated wetlands influence landscape functions? PNAS 113:1978-1986.

Conway, Courtney J., Christopher P. Nadeau, and Linden Piest. 2010. Fire helps restore natural disturbance regime to benefit rare and endangered marsh birds endemic to the Colorado River. Ecological Applications 20:2024-2035.

Daubenmire, R. F. 1959. A canopy-cover method of vegetational analysis. Northwest Science $33: 43-46$.

de Szalay, F. A., and V. H. Resh. 1997. Responses of wetland invertebrates and plants important in waterfowl diets to burning and mowing of emergent vegetation. Wetlands 17:149-156. 
485 Erwin, K. J., H. C. Chandler, J. G. Palis, T. A. Gorman, and C. A. Haas. 2016. Herpetofaunal

486

487

488

489

490

491

492

493

494

495

496

497

498

499

500

501

502

503

504

505

506 communities in ephemeral wetlands embedded within longleaf pine flatwoods of the Gulf Coastal Plain. Southeastern Naturalist 15:431-447.

Fazi, S., and L. Rossi. 2000. Effects of macro-detritivores density on leaf detritus processing rate: A macrocosm experiment. Hydrobiologia 435:127-134.

Fuell, A. K., S. A. Entrekin, G. S. Owen, and S. K. Owen. 2013. Drivers of leaf decomposition in two wetland types in the Arkansas River Valley, U.S.A. Wetlands 33:1127-1137.

Frost, C. C. 1993. Four centuries of changing landscape patterns in the longleaf pine ecosystem. Pages 17-43 in S. M. Hermann, editor. Proceedings of the Tall Timbers Fire Ecology Conference, No. 18, The Longleaf Pine Ecosystem: Ecology, Restoration and Management. Tall Timbers Research Station, Tallahassee, Florida.

Gilliam, F. S., and W. J. Platt. 1999. Effects of long-term fire exclusion on tree species composition and stand structure in an old-growth Pinus palustris (Longleaf pine) forest. Plant Ecology 140:15-26.

Gingerich, R. T., D. G. Panaccione, and J. T. Anderson. 2015. The role of fungi and invertebrates in litter decomposition in mitigated and reference wetlands. Limnologica $54: 23-32$.

Gleason, J. E., and R. C. Rooney. 2017. Pond permanence is a key determinant of aquatic macroinvertebrate community structure in wetlands. Freshwater Biology 63:264-277.

Glitzenstein, J. S., D. R. Streng, and D. D. Wade. 2003. Fire frequency effects on Longleaf Pine (Pinus palustris P. Miller) vegetation in South Carolina and Northeast Florida, USA. Natural Areas Journal 23:22-37. 
507 Golladay, S. W., B. A. Clayton, S. T. Brantley, C. R. Smith, J. Qi, and D. W. Hicks. 2021. Forest 508 restoration increases isolated wetland hydroperiod: a long-term case study. Ecosphere.

509 12:e03495.

510 Golladay, S. W., B. W. Taylor, and B. J. Palik. 1997. Invertebrate communities of forested

511 limesink wetlands in southwest Georgia, USA: Habitat use and influence of extended 512 inundation. Wetlands 17:383-393.

513 Gorman, T. A., C. A. Haas, and D. C. Bishop. 2009. Factors related to occupancy of breeding $514 \quad$ wetlands by flatwoods salamander larvae. Wetlands 29:323-329.

515 Gorman, T. A., C. A. Haas, and J. G. Himes. 2013. Evaluating methods to restore amphibian 516 habitat in fire-suppressed pine flatwoods wetlands. Fire Ecology 9:96-109.

517 Gorman, T. A., S. D. Powell, K. C. Jones, and C. A. Haas. 2014. Microhabitat characteristics of 518 egg deposition sites used by reticulated flatwoods salamanders. Herpetological $519 \quad$ Conservation and Biology 9:543-550.

520 Henderson, J. P. 2006. Dendroclimatological analysis and fire history of Longleaf Pine (Pinus palustris Mill.) in the Atlantic and Gulf Coastal Plain. Dissertation, University of

523 Hisabae, M., S. Sone, and M. Inoue, 2010. Breakdown and macroinvertebrate colonization of 524 needle and leaf litter in conifer plantation streams in Shikoku, southwestern Japan. $525 \quad$ Journal of Forest Research 16:106-115.

526 Hornung, J. P., and A. L. Foote. 2006. Aquatic invertebrate responses to fish presence and 527 vegetation complexity in western boreal wetlands, with implications for waterbird productivity. Wetlands 26:1-12. 
529 Jeffries, M. 1993. Invertebrate colonization of artificial pondweeds of differing fractal

530 dimension. Oikos 67:142-148.

531 Johnstone, J. F., C. D. Allen, J. F. Franklin, L. E. Frelich, B. J. Harvey, P. E. Higuera, M. C.

532 Mack, R. K. Meentemeyer, M. R. Metz, G. L. W. Perry, T. Schoennagel, and M. G.

533 Turner. 2016. Changing disturbance regimes, ecological memory, and forest resilience.

$534 \quad$ Frontiers in Ecology and the Environment 14:369-378.

535 Kirkman, L. K. 1995. Impacts of fire and hydrological regimes on vegetation in depression

536 wetlands of southeastern USA. In S. I. Cerulian and R. T. Engstrom, editors. Fire in

537 wetlands: A management perspective. Proceedings of the Tall Timbers Fire Ecology

538 Conference, Tall Timbers Research Station, Tallahassee, Florida.

539 Kirkman, L. K., S. W. Golladay, L. Laclaire, and R. D. Sutter. 1999. Biodiversity in

540 southeastern, seasonally ponded, isolated wetlands: Management and policy perspectives

541 for research and conservation. Journal of the North American Benthological Society

$542 \quad 18: 553-562$.

543 Lenth, R. V. 2021. emmeans: Estimated marginal means, aka Least-squares means. R package

$544 \quad$ version 1.6.3.

545 Leroy, C. J., and J. C. Marks. 2006. Litter quality, stream characteristics and litter diversity

546 influence decomposition rates and macroinvertebrates. Freshwater Biology 51:605-617.

547 Long, J. N. 2009. Emulating natural disturbance regimes as a basis for forest management: A

$548 \quad$ North American view. Forest Ecology and Management 257:1868-1873.

549 Maloney, D. C., and G. A. Lamberti. 1995. Rapid decomposition of summer -input leaves in a northern Michigan stream. The American Midland Naturalist 133:184-195. 
551 McInerney, Paul J., R. J. Stoffels, M. E. Shackleton, and C. D. Davey. 2017. Flooding drives a

552

553

554

555

556

557

558

559

560

561

562

563

564

565

566

567

568

569

570

571

572 573

macroinvertebrate biomass boom in ephemeral floodplain wetlands. Freshwater Science $36: 727-738$.

McLaughlin, D. L., D. A. Kaplan, and M. J. Cohen. 2013. Managing forests for increased regional water yield in the southeastern U.S. Coastal Plain. Journal of American Water Resource Association 49:953-965.

Morgan, P., C. C. Hardy, T. W. Swetnam, M. G. Rollins, and D. G. Long. 2001. Mapping fire regimes across time and space: Understanding coarse and fine-scale fire patterns. International Journal of Wildland Fire 10:329-342.

Mouillot, F., and C. B. Field. 2005. Fire history and the global carbon budget: $\mathrm{A} 1^{\circ} \times 1^{\circ}$ fire history reconstruction for the 20th century. Global Change Biology 11:398-420.

Mulhouse, J. M., D. D. Steven, R. F. Lide, and R. R. Sharitz. 2005. Effects of dominant species on vegetation change in Carolina bay wetlands following a multi-year drought. Journal of the Torrey Botanical Society 132:411-420.

Murkin, H. R., and D. A. Wrubleski. 1988. Aquatic invertebrates of freshwater wetlands: Function and ecology. Pp. 239-249 in The Ecology and Management of Wetlands. Springer, New York, NY.

Oksanen, J., F. G. Blanchet, M. Friendly, R. Kindt, P. Legendre, D. McGlinn, P. R. Minchin, R. B. O'Hara, G. L. Simpson, P. Solymos, M. H. H. Stevens, E. Szoecs, and H. Wagner. 2019. vegan: Community Ecology Package. R package version 2.5-6. https://CRAN.Rproject.org/package=vegan.

Palis, J. G. 1996. Flatwoods salamander (Ambystoma cingulatum Cope). Natural Areas Journal 16:49-54. 
574 Petersen, R. C., and K. W. Cummins. 1974. Leaf processing in a woodland stream. Freshwater $575 \quad$ Biology 4:343-368.

576 Peterson, D. W., and P. B. Reich. 2008. Fire frequency and tree canopy structure influence plant $577 \quad$ species diversity in a forest-grassland ecotone. Plant Ecology 194:5-16.

578 Polyakova, O., and N. Billor, 2007. Impact of deciduous tree species on litterfall quality, 579 decomposition rates and nutrient circulation in pine stands. Forest Ecology and $580 \quad$ Management 253:11-18.

581 Powell, T.L., G. Starr, K.L. Clark, T.A. Martin, and H.L. Gholz. 2005. Ecosystem and

582

583

584

585

586

587

588

589

590

591

592

593

594

595 understory water and energy exchange for a mature, naturally regenerated pine flatwoods forest in north Florida. Canadian Journal of Forest Research 35:1568-1580.

R Core Team. 2020. R: A language and environment for statistical computing. R Foundation for Statistical Computing, Vienna, Austria. URL https://www.R-project.org/.

Sekerak, C. M., G. W. Tanner, and J. G. Palis. 1996. Ecology of flatwoods salamander larvae in breeding ponds in Apalachicola National Forest. Proceedings of the Annual Conference of the Southeastern Association of Fish and Wildlife Agencies 50:321-30.

Smith, L. L., A. L. Subalusky, C. L. Atkinson, J. E. Earl, D. M. Mushet, D. E. Scott, S. L. Lance, and S. A. Johnson. 2019. Biological connectivity of seasonally ponded wetlands across spatial and temporal scales. Journal of the American Water Resources Association $55: 334-353$.

Stambaugh, M. C., R. P. Guyette, and J. M. Marshall. 2011. Longleaf pine (Pinus palustris Mill.) fire scars reveal new details of a frequent fire regime. Journal of Vegetation Science 22:1094-1104. 
596 Stoler, A. B., and R. A. Relyea. 2016. Leaf litter species identity alters the structure of pond 597 communities. Oikos 125:179-191.

598 Sun, G., C. Li, C. C. Trettin, J. Lu, and S.G. McNulty. 2006. Simulating the biogeochemical 599 cycles in cypress wetland-pine upland ecosystems at a landscape scale with the wetland-

600 DNDC model. In Hydrology and Management of Forested Wetlands: Proceedings of the

601 International Conference. Pp. 261-270.

602

603

604 streams. Journal of the North American Benthological Society 27:321-331.

605 606

Tietema, A., and W. W. Wessel. 1993. Microbial activity and leaching during initial oak leaf litter decomposition. Biology and Fertility of Soils 18:49-54.

607

Tiner, R. W. 2003. Geographically isolated wetlands of the United States. Wetlands 23:494-516.

609

Townsend, Colin R., and Mike R. Scarsbrook. 1997. The intermediate disturbance hypothesis, refugia, and biodiversity in streams. Limnology and Oceanography 42:938-949.

Turner, M. G. Disturbance and landscape dynamics in a changing world. Ecology 91:2833-2849.

611

U. S. Fish and Wildlife Service. 2009. Endangered and threatened wildlife and plants;

612 determination of endangered status for Reticulated Flatwoods Salamander; designation of critical habitat for Frosted Flatwoods Salamander and Reticulated Flatwoods Salamander. Federal Register 74:6700-6773.

Watts, A. C. 2013. Organic soil combustion in cypress swamps: Moisture effects and landscape 616 implications for carbon release. Forest Ecology and Management 294:178-187. 
617 Wendt, A., C. A. Haas, T. A. Gorman, and J. H. Roberts. 2021. Metapopulation genetics of 618 endangered reticulated flatwoods salamanders (Ambystoma bishopi) in a dynamic and 619 fragmented landscape. Conservation Genetics 22:551-567.

620 Werner, E. E., and K. S. Glennemeier. 1999. Influence of forest canopy cover on the breeding 621 pond distributions of several amphibian species. Copeia 1999:1-12.

622 Whiles, M. R., J. B. Jensen, J. G. Palis, and W. G. Dyer. 2004. Diets of larval Flatwoods 623 Salamanders, Ambystoma cingulatum, from Florida and South Carolina. Journal of $624 \quad$ Herpetology 38:208-214.

625 White, P. S., and A. Jentsch. 2001. The search for generality in studies of disturbance and 626 ecosystem dynamics. Progress in Botany 62:399-450.

627 White, P. S., and S. T. A. Pickett. 1985. Natural disturbance and patch dynamics: an 628 introduction. Pp. 3-13 in S. T. A. Pickett and P. S. White, editors. The ecology of natural disturbance and patch dynamics. Academic Press, New York, New York, USA. invertebrates in two prairie wetlands, with and without fish, with implications for community production. Freshwater Biology 46:1373-1386. 


\section{Table $\mathbf{1}$ (on next page)}

Leaf litter breakdown metrics recorded in pine flatwoods wetlands on Eglin Air Force Base, Florida.

Breakdown metrics for three plant species (Longleaf Pine [Pinus palustris], Pineland Threeawn Grass [Aristida stricta], and Black Gum [Nyssa sy/vatica]) after 103-104 days submerged. Leaf packs were placed in sections of wetlands with vegetation characteristics indicative of fire-maintained and fire-suppression habitat. Values represent means \pm standard deviations from three leaf packs of each species. The processing coefficient $(k)$ was estimated using an exponential decay model. 


\begin{tabular}{|c|c|c|c|}
\hline \multicolumn{2}{|r|}{$\%$ Litter } & $k$ & \multirow[t]{2}{*}{$\begin{array}{c}\text { Days to } 99 \% \\
\text { Decomposition }\end{array}$} \\
\hline \multicolumn{3}{|l|}{ Pond 53} & \\
\hline \multicolumn{4}{|l|}{ Fire Maintained } \\
\hline A. stricta & $0.78 \pm 0.01$ & $-0.0024 \pm 0.0001$ & $1898 \pm 91$ \\
\hline P. palustris & $0.77 \pm 0.004$ & $-0.0025 \pm 0.0001$ & $1857 \pm 37$ \\
\hline N. sylvatica & $0.50 \pm 0.01$ & $-0.0067 \pm 0.0002$ & $688 \pm 24$ \\
\hline \multicolumn{4}{|l|}{ Fire Suppressed } \\
\hline A. stricta & $0.81 \pm 0.02$ & $-0.0020 \pm 0.0002$ & $2305 \pm 261$ \\
\hline P. palustris & $0.78 \pm 0.01$ & $-0.0024 \pm 0.0001$ & $1906 \pm 87$ \\
\hline N. sylvatica & $0.63 \pm 0.01$ & $-0.0045 \pm 0.0001$ & $1020 \pm 24$ \\
\hline \multicolumn{4}{|l|}{ Pond 16} \\
\hline \multicolumn{4}{|l|}{ Fire Maintained } \\
\hline A. stricta & $0.77 \pm 0.02$ & $-0.0025 \pm 0.0003$ & $1843 \pm 187$ \\
\hline P. palustris & $0.76 \pm 0.01$ & $-0.0027 \pm 0.0001$ & $1728 \pm 88$ \\
\hline N. sylvatica & $0.52 \pm 0.04$ & $-0.0064 \pm 0.0007$ & $721 \pm 72$ \\
\hline \multicolumn{4}{|l|}{ Fire Suppressed } \\
\hline A. stricta & $0.80 \pm 0.01$ & $-0.0021 \pm 0.0001$ & $2174 \pm 132$ \\
\hline P. palustris & $0.76 \pm 0.01$ & $-0.0027 \pm 0.0002$ & $1713 \pm 97$ \\
\hline N. sylvatica & $0.51 \pm 0.03$ & $-0.0065 \pm 0.0006$ & $714 \pm 65$ \\
\hline \multicolumn{4}{|l|}{ Pond 12} \\
\hline \multicolumn{4}{|l|}{ Fire Maintained } \\
\hline A. stricta & $0.79 \pm 0.01$ & $-0.0023 \pm 0.0001$ & $2017 \pm 75$ \\
\hline P. palustris & $0.75 \pm 0.01$ & $-0.0028 \pm 0.0001$ & $1645 \pm 71$ \\
\hline N. sylvatica & $0.53 \pm 0.02$ & $-0.0062 \pm 0.0003$ & $749 \pm 34$ \\
\hline \multicolumn{4}{|l|}{ Fire Suppressed } \\
\hline A. stricta & $0.79 \pm 0.01$ & $-0.0023 \pm 0.0001$ & $2022 \pm 79$ \\
\hline P. palustris & $0.73 \pm 0.02$ & $-0.0030 \pm 0.0003$ & $1535 \pm 159$ \\
\hline N. sylvatica & $0.50 \pm 0.03$ & $-0.0067 \pm 0.0005$ & $692 \pm 51$ \\
\hline
\end{tabular}




\section{Table 2 (on next page)}

Parameter estimates for three linear mixed effects models.

Linear mixed effects models estimated the effects of habitat type (fire suppressed or fire maintained) and leaf litter species (Longleaf Pine [Pinus palustris], Pineland Threeawn Grass [Aristida stricta], and Black Gum [Nyssa sylvatica]) on leaf litter breakdown, invertebrate relative abundance, and the relative abundance of invertebrate groups that are important prey items for larval flatwoods salamanders. Leaf litter breakdown and invertebrate communities were measured using leaf packs in three wetlands on Eglin Air Force Base, Florida. 


\begin{tabular}{clccc}
\hline Model & Habitat & Leaf Species & Estimate & Standard Error \\
\hline Leaf Litter Breakdown & Fire Suppressed & N. sylvatica & 8.21 & 0.18 \\
& Fire Suppressed & P.palustris & 3.13 & 0.20 \\
& Fire Suppressed & A. stricta & 3.83 & 0.21 \\
& Fire Maintained & - & -0.48 & 0.20 \\
Invertebrate Relative & Fire Suppressed & N. sylvatica & 31.53 & 10.17 \\
Abundance & Fire Suppressed & P.palustris & -18.12 & 12.70 \\
& Fire Suppressed & A. stricta & -4.14 & 13.10 \\
& Fire Maintained & - & 16.73 & 12.70 \\
Relative Larval Flatwoods & Fire Suppressed & N. sylvatica & 18.78 & 3.00 \\
Salamander Prey Abundance & Fire Suppressed & $P$. palustris & -14.16 & 3.63 \\
& Fire Suppressed & A. stricta & -9.80 & 3.74 \\
& Fire Maintained & - & -2.82 & 3.63 \\
\hline
\end{tabular}

1 


\section{Table 3 (on next page)}

Invertebrate abundance in leaf packs that were placed in pine flatwoods wetlands on Eglin Air Force Base, Florida.

Invertebrate groups collected in 54 leaf litter packs submerged for 103-104 days in ephemeral wetlands. Leaf packs containing either Longleaf Pine (Pinus palustris), Pineland Threeawn Grass (Aristida stricta), or Black Gum (Nyssa sylvatica) were placed in either firesuppressed or fire-maintained habitat in three wetlands. Values represent the mean $( \pm$ standard deviation) abundance of each invertebrate group averaged across nine replicates. Taxonomic groups marked with an asterisk were dominated by a single family but were grouped to higher taxonomic levels for all analyses (Isopoda - Asellidae, Amphipoda Gammaridae, Diptera - Chironomidae, Hemiptera - Corixidae, Zygoptera - Coenagrionidae, Acariformes - Hydrachnidae, Gastropoda - Planorbidae). 


\begin{tabular}{|c|c|c|c|c|c|c|}
\hline & \multicolumn{3}{|c|}{ Fire Suppressed } & \multicolumn{3}{|c|}{ Fire Maintained } \\
\hline & Gum & Pine & Wiregrass & Gum & Pine & Wiregrass \\
\hline Isopoda* & $129.3 \pm 113.3$ & $41.4 \pm 52.1$ & $80.4 \pm 70.6$ & $105.0 \pm 40.5$ & $42.6 \pm 36.1$ & $91.7 \pm 57.7$ \\
\hline Amphipoda* & $8.6 \pm 4.0$ & $9.4 \pm 8.6$ & $13.8 \pm 26.6$ & $12.6 \pm 23.3$ & $2.0 \pm 2.7$ & $5.4 \pm 5.5$ \\
\hline Anostraca & $0.1 \pm 0.3$ & - & - & - & - & - \\
\hline Cladocera & $23.0 \pm 23.7$ & $9.6 \pm 7.3$ & $62.1 \pm 81.2$ & $189.8 \pm 329.1$ & $64.0 \pm 93.9$ & $127.8 \pm 182.0$ \\
\hline Copepoda & $7.7 \pm 5.7$ & $1.3 \pm 1.4$ & $5.7 \pm 4.3$ & $4.0 \pm 4.2$ & $1.0 \pm 1.3$ & $1.2 \pm 1.7$ \\
\hline Decapoda & - & - & - & $0.2 \pm 0.4$ & - & - \\
\hline Diptera* & $38.2 \pm 13.7$ & $24.7 \pm 20.8$ & $22.6 \pm 17.9$ & $12.3 \pm 5.3$ & $9.7 \pm 11.2$ & $12.1 \pm 14.0$ \\
\hline Hemiptera* & - & $0.2 \pm 0.4$ & - & - & $0.1 \pm 0.3$ & $0.2 \pm 0.4$ \\
\hline Coleoptera & $0.2 \pm 0.4$ & $0.1 \pm 0.3$ & - & $0.1 \pm 0.3$ & $0.1 \pm 0.3$ & $1.6 \pm 2.3$ \\
\hline Odonata & - & $0.1 \pm 0.3$ & - & - & - & - \\
\hline Anisoptera & - & - & - & $0.6 \pm 1.3$ & $0.2 \pm 0.7$ & $0.1 \pm 0.3$ \\
\hline Zygoptera* & - & 一 & 一 & $1.0 \pm 1.4$ & $1.6 \pm 2.4$ & $2.7 \pm 3.8$ \\
\hline Acariformes* & $38.3 \pm 69.7$ & $63.2 \pm 96.7$ & $122.8 \pm 170.0$ & $21.4 \pm 25.2$ & $56.8 \pm 64.4$ & $69.2 \pm 67.9$ \\
\hline Collembola & $0.3 \pm 0.7$ & $0.0 \pm 0.0$ & $0.3 \pm 1.0$ & $0.2 \pm 0.4$ & $0.1 \pm 0.3$ & - \\
\hline Gastropoda* & $1.2 \pm 2.6$ & $0.7 \pm 1.3$ & $0.1 \pm 0.3$ & $14.4 \pm 20.3$ & $2.8 \pm 3.3$ & $2.3 \pm 4.2$ \\
\hline
\end{tabular}




\section{Figure 1}

Mass loss for Longleaf Pine (Pinus palustris), Pineland Threeawn Grass (Aristida stricta), and Black Gum (Nyssa sylvatica) measured in three pine flatwoods wetlands on Eglin Air Force Base.

(A) Mass loss from fire-maintained habitats. (B) Mass loss from fire-suppressed habitats. Solid lines represent the non-linear least squares fit for each group, approximating the rate of mass loss over time using 25-day leaf packs collected in a single wetland. 
A)

Species $\rightarrow$ N. sylvatica $\multimap$ P. palustris $\longrightarrow$ A. stricta

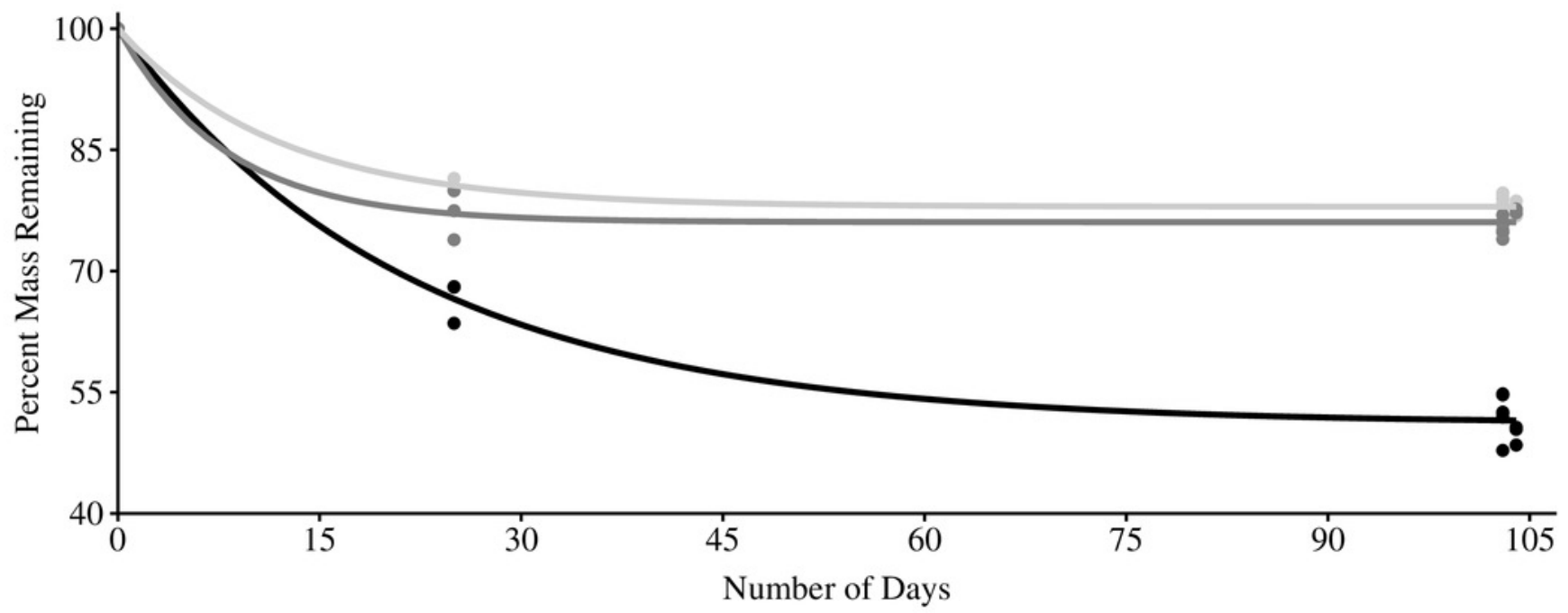

B)

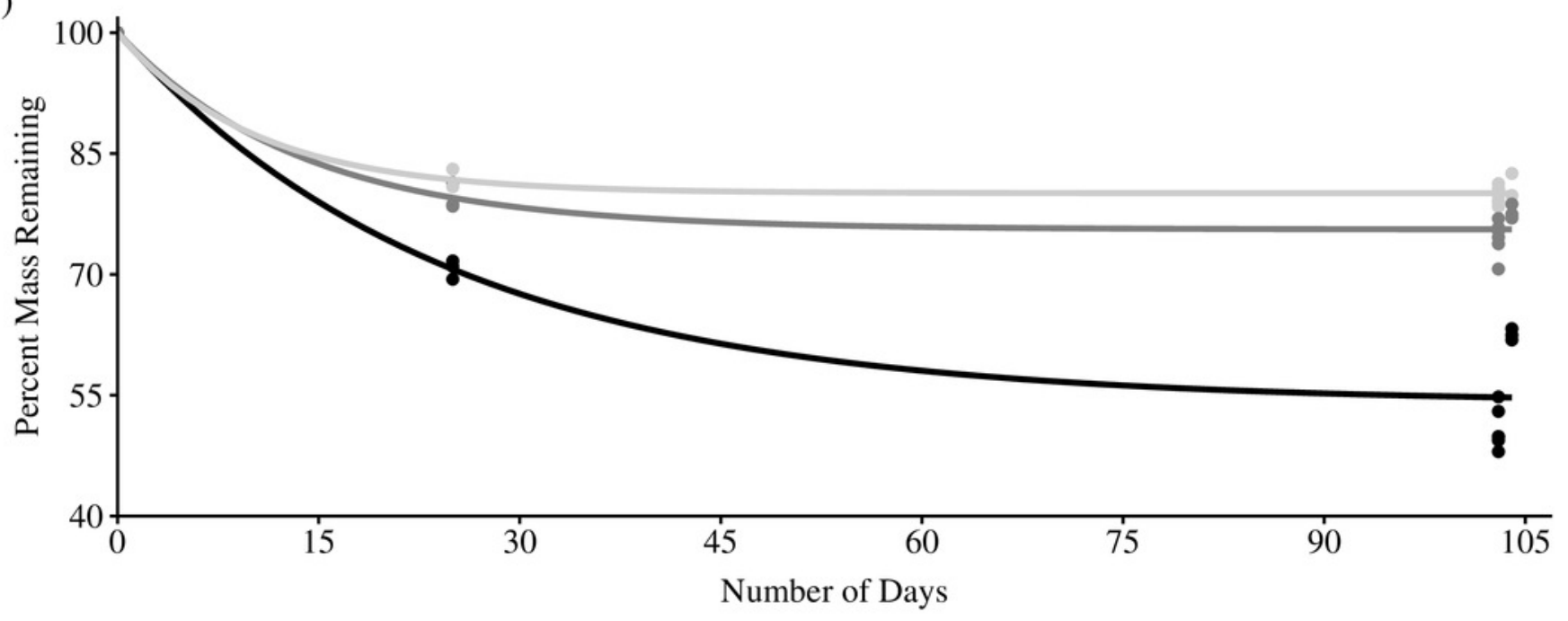




\section{Figure 2}

Invertebrate relative abundance measured in leaf packs in three pine flatwoods wetlands on Eglin Air Force Base, Florida.

(A) Total relative invertebrate abundance. (B) Relative abundance of taxa (Isopoda, Amphipoda, and Copepoda) important to larval flatwoods salamander diets. Leaf packs represented one of six treatments that varied by leaf type and the overall habitat type in that portion of the wetland (FS-G: fire-suppressed, Black Gum [Nyssa sylvatica]; FS-P: firesuppressed, Longleaf Pine [Pinus palustris]; FS-W: fire-suppressed, Pineland Threeawn Grass, commonly referred to as wiregrass, [Aristida stricta]; FM-G: fire-maintained, N. sylvatica; FMP: fire-maintained, P. palustris; FM-W: fire-maintained, $A$. stricta). Relative abundance is calculated as the number of invertebrates divided by the dry mass of remaining leaf litter, and polygons represent the mirrored kernel density plot, showing the smoothed distribution of the data points. 
A)

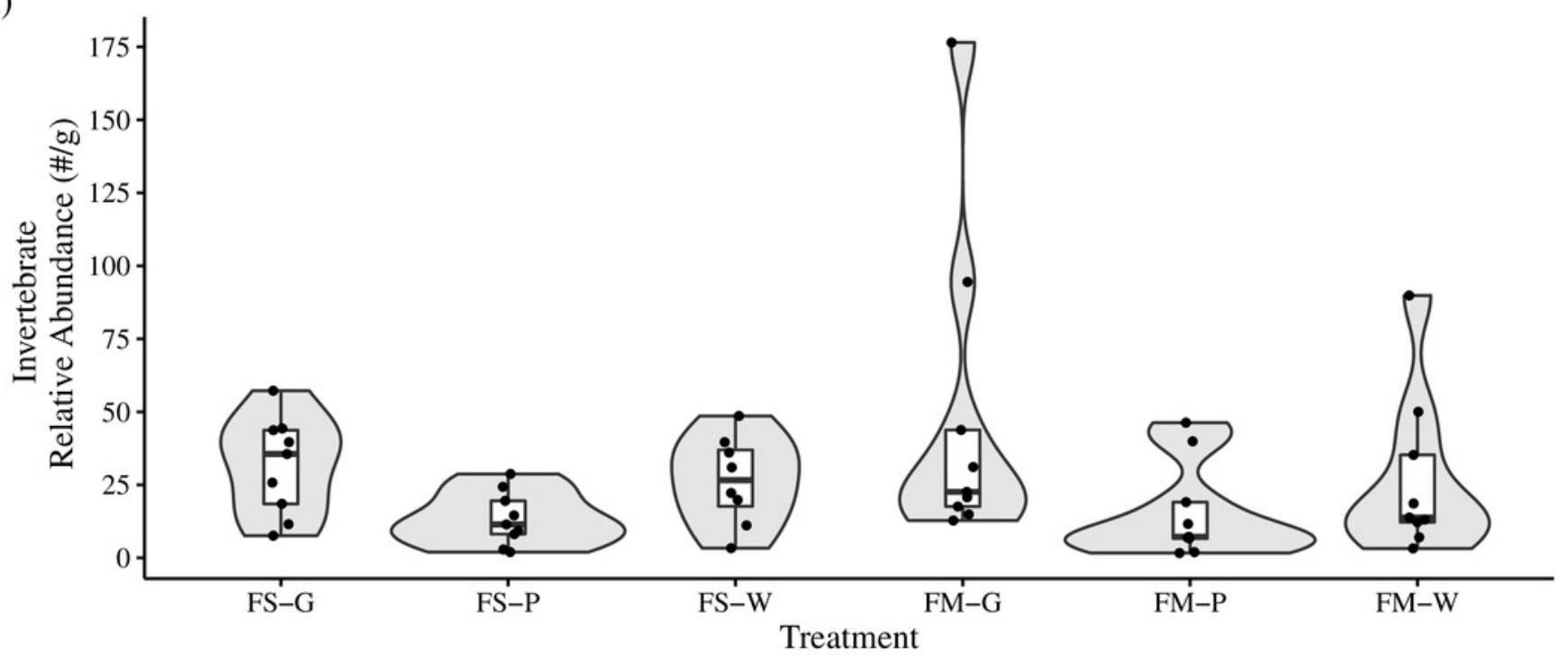

B)

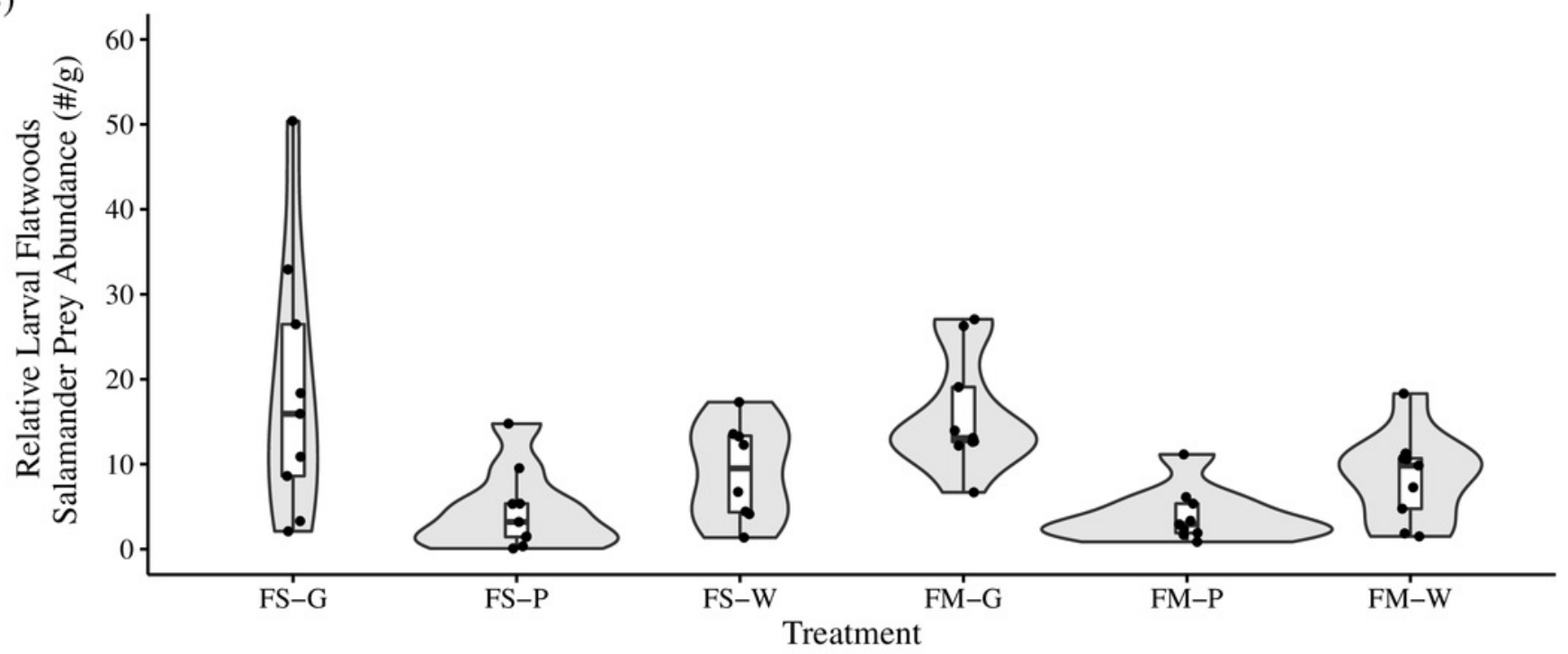




\section{Figure 3}

Non-metric Multidimensional Scaling (NMDS) plots of invertebrate communities measured in leaf packs from pine flatwoods wetlands on Eglin Air Force Base, Florida.

(A) Leaf packs were placed in either fire-suppressed or fire-maintained habitat. (B) Leaf packs contained one of three leaf types: Longleaf Pine (Pinus palustris), Pineland Threeawn Grass (Aristida stricta), or Black Gum (Nyssa sylvatica). 
A)

$\bullet$ Fire Suppressed $\triangle$ Fire Maintained

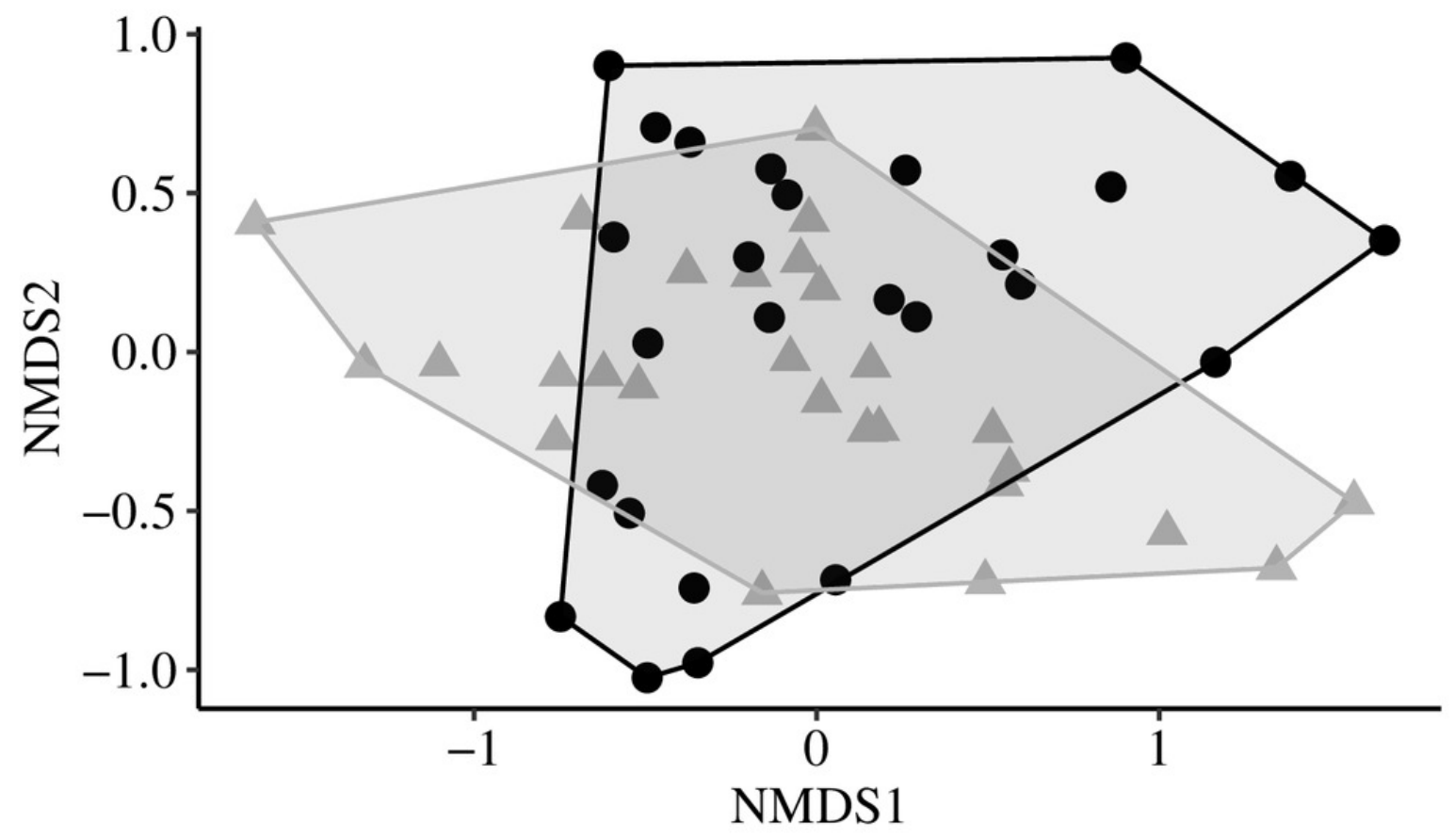

B)

$\bullet$ N. sylvatica $\Delta$ P. palustris $\square$ A. stricta

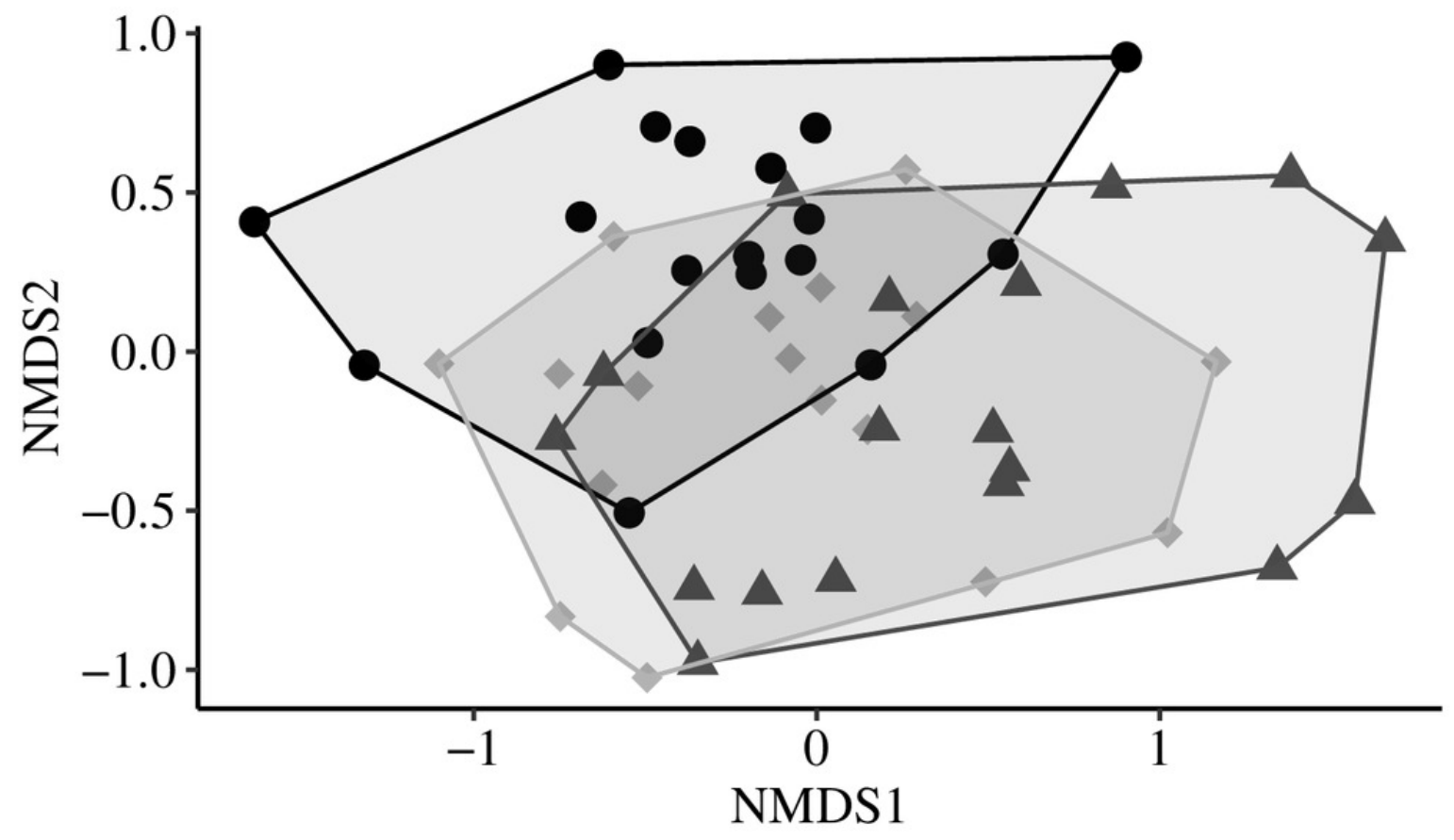

